\title{
The oil shale formation mechanism of the Songliao Basin Nenjiang Formation triggered by marine transgression and oceanic anoxic events 3
}

\author{
Wentong $\mathrm{He}^{(\mathrm{a}, \mathrm{b}, \mathrm{c})}$, Xuanlong Shan ${ }^{(\mathrm{e})^{*}}$, Youhong Sun ${ }^{(\mathrm{a}, \mathrm{b}, \mathrm{d})}$, Hansheng $\mathrm{Cao}^{(\mathrm{f})}$, \\ Shaopeng Zheng ${ }^{(a)}$, Siyuan $\mathrm{Su}^{(\mathrm{e}, \mathrm{g})}$, Shijie Kang ${ }^{(\mathrm{a})}$
}

(a) College of Construction Engineering, Jilin University, Changchun, China

(b) National-Local Joint Engineering Laboratory of In-situ Conversion, Drilling and Exploitation Technology for Oil Shale, Jilin University, Changchun, China

(c) Key Laboratory of Oil Shale and Coexistent Energy Minerals of Jilin Province, Changchun, China

(d) School of Engineering and Technology, China University of Geosciences, Beijing, China

(e) College of Earth Sciences, Jilin University, Changchun, China

(f) College of Ocean and Meteorology, Guangdong Ocean University, Zhanjiang, China

(g) Shandong Provincial Key Laboratory of Depositional Mineralization \& Sedimentary Mineral, Shandong University of Science and Technology, Qingdao, China

Received 30.05.2020, accepted 16.05.2021, available online 10.06.2021

\begin{abstract}
The influence of oceanic anoxic events 3 (OAE3) and transgression events during the Coniacian-Santonian boundary period on the sedimentary paleoenvironment of Nenjiang Formation strata and the oil shale formation mechanism is not clear yet. The high-precision determination of elements, stable isotopes and biomarkers of the Nenjiang Formation oil shale samples was tested in this study. The study showed that the source of organic matter (OM) of the Nenjiang Formation oil shale was a mixture of aquatic organisms (algae and bacteria) and higher plants. Some geochemical parameters also indicated that the OM in the formation might contain a certain amount of marine organic matter. Under $\mathrm{OAE3}$, the $\mathrm{pCO}_{2}$ and warm and humid paleoclimate caused an increase in the total organic carbon (TOC) and the organic carbon isotope $\left(\delta^{13} C_{\text {org }}\right)$ negative deviation near the Santonian-Campanian $(S-C)$ boundary. Seawater entered the Songliao Lake Basin, and the nutrient composition, water density stratification and sulfate content increased. The reducing environment of the bottom water was conducive to the accumulation and burial of organic matter. With increasing sulfate content, the total organic carbon/total sulfur (TOC/TS)
\end{abstract}

\footnotetext{
* Corresponding author: e-mailshanxl@jlu.edu.cn

(C) 2021 Authors. This is an Open Access article distributed under the terms and conditions of the Creative Commons Attribution-NonCommercial 4.0 International License (http://creativecommons.org/licenses/by-nc/4.0/).
} 
in the formation decreased, and the sulfate $\delta^{34} S$ produced a negative bias. Under the influence of OAE3 and transgression events, the paleoenvironment of oil shale formation in the Nenjiang Formation was divided into four stages.

Keywords: Nenjiang Formation, marine transgression, oceanic anoxic events 3 , oil shale formation mechanism, Songliao Basin.

\section{Introduction}

The geological and paleoenvironmental characteristics of Cretaceous events are revealed by greenhouse climate and oceanic anoxic events (OAEs) [1]. Oceanic anoxic events that occurred during the periods of Aptian-Albian, Cenomanian-Turonian and Coniacian-Santonian are known as OAE1, OAE2 and OAE3, respectively. OAEs may be related to increased concentrations of greenhouse gases in the atmosphere [2], while the increase in greenhouse gas concentration during the Santonian-Campanian $(\mathrm{S}-\mathrm{C})$ boundary period may be enhanced by rifting and volcanism [3]. During the OAE3 period, large amounts of organic-rich sediments appeared [4], and various source rocks were formed in the marine bed [1]. However, it has not been reported whether OAE3 had a global impact [5] and whether it could have affected the sedimentary predecessors of the Songliao Continental Basin in the same period. In 2013, Deng et al. [6] measured the U-Pb age of bentonite in the Nenjiang Formation bottom oil shale formation to be approximately 83.7 Ma, which is close to $83.5 \mathrm{Ma}$ ( $\mathrm{S}-\mathrm{C}$ boundary) [7].

The Kula and Iznaaki plates experienced sudden changes in their subduction directions at $90 \mathrm{Ma}, 84 \mathrm{Ma}$ and $71 \mathrm{Ma}$, ranging from $\mathrm{N} 35^{\circ} \mathrm{W}$ to $\mathrm{N} 15^{\circ} \mathrm{W}$ and then to $\mathrm{N} 0^{\circ} \mathrm{W}$. The sinistral strike-slip system generated by this plate movement could have led seawater westward into the lake basin $[8,9]$. Moreover, the formation of the Nenjiang Formation in the Songliao Basin also occurred at $84 \mathrm{Ma}$. Glauconite is often regarded as a marker mineral, indicating the distinction between marine and terrestrial layers [10]. Xing et al. [11] studied glauconite in the Songliao Basin and showed that the one in the Nenjiang Formation layer was glauconite illite that formed in a freshwaterbrackish water environment. Euryhaline dinoflagellates and fish found in the Nenjiang Formation layer lived well in a saline water environment and include biomarkers with marine characteristics, such as gammacerane [11-13]. Foraminifera fossils have been found in the Nenjiang Formation, which further proves the existence of marine organisms in the Songliao Basin [14]. With the goal of determining how marine transgression affected the Nenjiang Formation deposits and the accumulation of organic matter in its layers, previous studies were limited by sampling accuracy and the use of specific research methods $[12,15,16]$. In the Southeastern Uplift area, Cretaceous strata are well preserved [17]. The current study sampled complete Cretaceous layer cores from scientific drilling in the Nong'an oil shale oilfield in the 
Southeastern Uplift area of the Songliao Basin and determined the elements, stable isotopes and biomarker compounds of the Nenjiang Formation cores. The aim was to provide an overview of the sedimentary paleoenvironment and oil shale formation mechanism of the Nenjiang Formation under the background of marine transgression and OAE3.

\section{Geological setting}

The Songliao Basin in Asia is a typical Cretaceous continental intracratonic rift basin with a long history and a complete fill sequence [18, 19] (Fig. 1). Based on the history of tectonic evolution, the Songliao Basin is divided into six structural units: the Central Downwarp, the Southeastern Uplift, the Southwestern Uplift, the Western Slope, the Northeastern Uplift and the Northern Plunge (Fig. 1). Among them, the Central Downwarp has accumulated the most important oil-bearing tectonic belts, including the Daqing Anticline, the Chaoyanggou Terrace and the Changling, Qijia-Gulong and Sanzhao sags (Fig. 1, [17]).
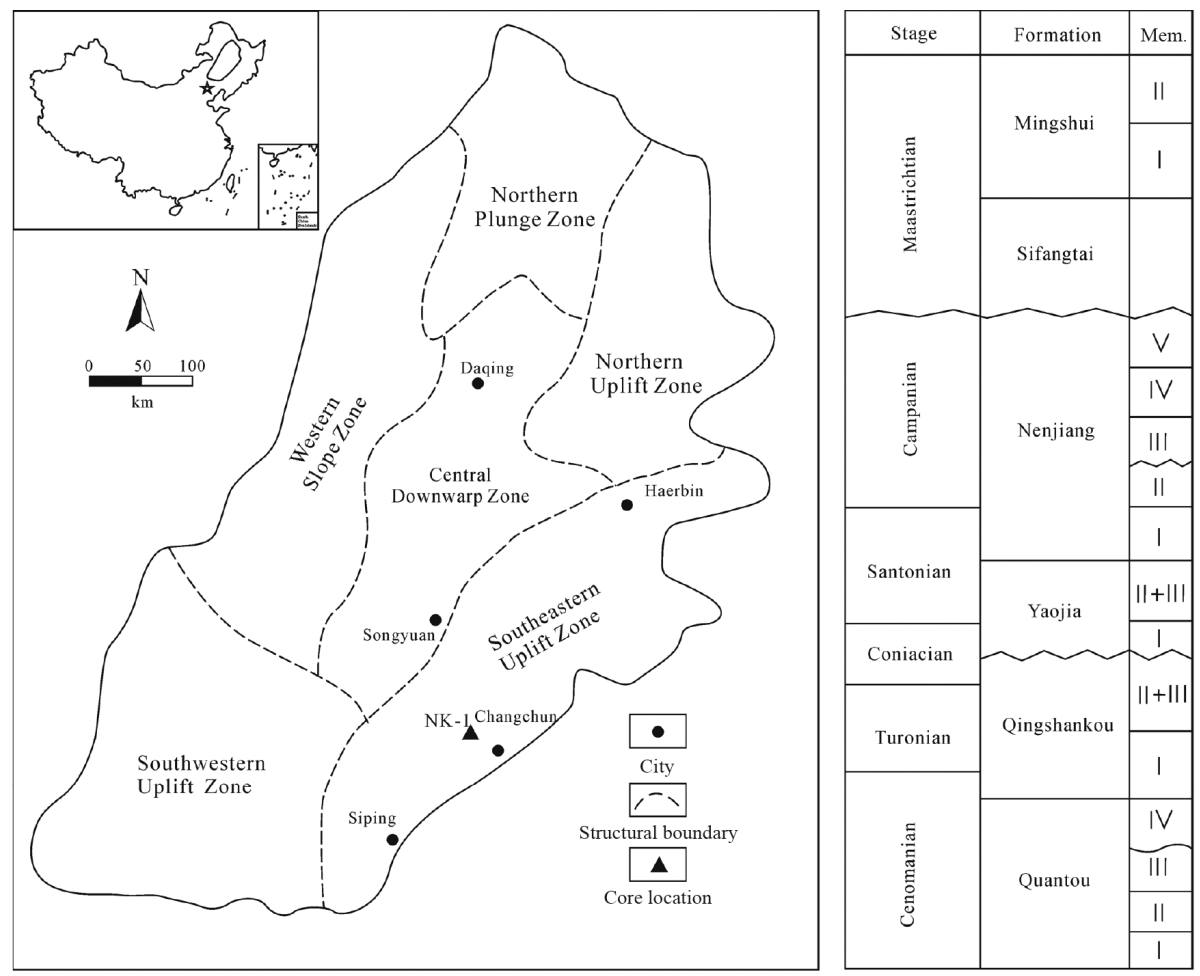

Fig. 1. Geological map and stratigraphy map of the Songliao Basin, northeastern China. The oil shale age is Nenjiang Formation of the Santonian-Campanian Stage of the Upper Cretaceous (revised from [17]). (Abbreviation: Mem. - Member.) 
The Nenjiang Formation is the largest lacustrine flooding deposit in the Songliao Basin. According to lithological assemblages, member 1 can be divided into five sections that are primarily black mudstone and thin oil shale deposits; member 2 is based on thick and stable oil shale layers in the whole area and transitions upwards into black mudstone and grey-green mudstone; members 3-5 of the Nenjiang Formation suffer denudation in the southeast of the basin (absence in the Nong'an area) and are composed of lime, green mudstone and grey-white sandstone in the basin centre and then transition to purple-red mudstone deposits. As stated above, the U-Pb age of bentonite was measured to be approximately $83.7 \mathrm{Ma}$ in the Nenjiang Formation bottom oil shale formation [6], which is close to the $83.5 \mathrm{Ma}$ ( $\mathrm{S}-\mathrm{C}$ boundary) determined by Wan et al. [7].

As regards biostratigraphy, the palaeontological characteristics of different sedimentary periods are different and not only represent the sequence of biological evolution but also provide good evidence for changes in the sedimentary environment. Among sporopollenites, Borealipollis dominates from the Yaojia Formation to the bottom of member 2 of the Nenjiang Formation, and Aquilapollenites dominates member 2 of the Nenjiang Formation. The main phytoplanktons of the Yaojia Formation are Pediastrum and Botryococcus, while Dinogy mniopsis minor-Balumla is prevalent in the Nenjiang Formation. The Upper Cretaceous Songliao Basin is rich in Ostracoda fossils. The Nenjiang Formation has a variety of fossil assemblages, including Cypridea gracila-Cypridea gunsulinensis, Cypridea anonyma-Candona fabiforma and Mongolocypris magna-Mongolicys helium chinensis. The fossil assemblages of member 2 include Cypridea liaukhenensis-Cypridea bella and Pricanthella portentosa-Limnocypridea subcalariformis. Foraminifera fossils, including Archaeoglobigerina blowi, Karrorulina hokkaidoana, Hedbergella flandrini, Gavlinella sp. and Anomalides sp., were found only in member 1 during the whole geohistory of the Songliao Basin [14, 20].

Exploration and drilling in the entire Songliao Basin showed that during the sedimentary period of the Nenjiang Formation (Santonian and Campanian stages), the lake surface was enlarged in places where oil shale was developed [21]. The oil shale in member 1 contains dolomite beds, which is consistent with the increasing salinity of transgressive marine facies. This view is supported by the observation of a single class of triangular ring-edged spiral groups in member 1 oil shale [14].

\section{Sampling and methods}

The NA-1 drilling was carried out $23 \mathrm{~km}$ north of Changchun City, and complete cores from the Yaojia Formation to the Nenjiang Formation were obtained (Fig. 1). All 124 core samples were washed to remove drilling fluid from the cores, dried at $80^{\circ} \mathrm{C}$ for $12 \mathrm{~h}$, and then ground to a 200 mesh particle 
size. The samples were tested for total sulfur (TS), total organic carbon (TOC), organic carbon isotope $\left(\delta^{13} \mathrm{C}_{\text {org }}\right)$ and sulfur isotope $\left(\delta^{34} \mathrm{~S}\right)$ contents. Six samples from depths of 45, 52, 66, 73, 79 and $92 \mathrm{~m}$ (NAO-1 to NAO-6) were selected for organic matter extraction, composition separation, gas-phase mass spectrometry of saturated hydrocarbons and isotope testing of hydrocarbon monomers.

$\mathrm{TS}, \delta^{34} \mathrm{~S}$, TOC and $\delta^{13} \mathrm{C}_{\text {org }}$ contents were determined by isotope ratio mass spectrometry (IRMS) with an ISOprime100 instrument and a vario PYRO cube elemental analyser (Elementar Analysensysteme $\mathrm{GmbH}$, Germany). Every ten samples were tested for quality against two standard samples, IAEA-SO-5 and GBW04408. According to the standard sample analysis, the error in analysis was better than $0.2 \%$. The standard protocols followed were GB/T 18340.2-2010 and DZT 0184.14-1997.

Six powdered oil shale samples (from depths of 45, 52, 66, 73, 79 and $92 \mathrm{~m} ; 20 \mathrm{~g}$ each) were extracted using a Soxhlet apparatus with a mixture of dichloromethane and methanol (93:7). The extractable organic matter (EOM) was separated into saturated hydrocarbon, aromatic hydrocarbon, and nitrogen, sulfur or oxygen (NSO) and asphaltene compounds by liquid chromatography. The saturated hydrocarbons were dissolved in petroleum ether and analysed by gas chromatography-mass spectrometry (GC-MS) using an Agilent 7890B-MSD with an HP-5 MS elastic quartz capillary GC column $(60 \mathrm{~m} \times 0.25 \mathrm{~mm} \times 0.25 \mathrm{~mm})$. The distribution of $\mathrm{n}$-alkanes and isoprene was determined by GC-MS, and the biomarkers were studied in detail. The standard protocol GBT-30431-2013 was followed.

The carbon isotope composition of specific compounds in the saturated hydrocarbon fraction was analysed by an Agilent 7890B GC coupled to an ISOprime100 isotope ratio mass spectrometer. The chromatographic column and temperature programme were the same as those applied in GC-MS experiments, and the error was better than $0.2 \%$.

\section{Results and discussion}

\section{1. Petrography}

According to observation of the NA-1 drilling core, the ore-bearing horizon of oil shale mainly occurs at member 1 and the bottom of member 2 . The main lithology of oil shale of member 1 is grey-black mudstone shale with greygreen argillaceous siltstone, grey-black oil shale with high organic abundance is developed, and grey-black shale is present in member 2 (Fig. 1). 


\subsection{Organic geochemistry}

\subsubsection{Bitumen bulk geochemical parameters}

The results of sample EOM component separation are shown in Table 1 and Figure 2. In these samples, the content of saturated hydrocarbons is the highest. The content of saturated hydrocarbons extracted from the shale samples is $21-50 \%$, with an average of $33 \%$. The average contents of aromatic hydrocarbons, NSO compounds and asphaltene are 19\%, 32\% and 16\%, respectively.

Table 1. Extractable organic matter yields and relative proportions of saturated hydrocarbon fractions, aromatic hydrocarbon fractions and NSO compounds

\begin{tabular}{|c|c|c|c|c|c|c|c|c|}
\hline \multirow{2}{*}{ Sample } & \multirow{2}{*}{$\begin{array}{l}\text { Depth, } \\
\text { m }\end{array}$} & \multirow{2}{*}{$\begin{array}{c}\text { Extractable } \\
\text { organic matter, } \\
\text { mg/g TOC }\end{array}$} & \multicolumn{6}{|c|}{ Chromatographic fractions of bitumen extraction, oil wt $\%$} \\
\hline & & & $\begin{array}{c}\text { Saturated } \\
\text { hydrocarbons }\end{array}$ & $\begin{array}{c}\text { Aromatic } \\
\text { hydrocarbons }\end{array}$ & \begin{tabular}{|c|} 
NSO \\
compounds
\end{tabular} & $\begin{array}{l}\text { Asphal- } \\
\text { tene }\end{array}$ & $\mathrm{HCs}$ & Sat/Aro \\
\hline NAO-1 & 45 & 2.73 & 21 & 27 & 47 & 4 & 49 & 0.79 \\
\hline NAO-2 & 52 & 4.32 & 25 & 15 & 32 & 28 & 40 & 1.67 \\
\hline NAO-3 & 66 & 6.23 & 28 & 20 & 35 & 18 & 48 & 1.45 \\
\hline $\mathrm{NAO}-4$ & 73 & 6.56 & 42 & 20 & 31 & 6 & 62 & 2.06 \\
\hline NAO-5 & 79 & 5.16 & 50 & 16 & 20 & 14 & 66 & 3.04 \\
\hline NAO-6 & 92 & 9.25 & 30 & 15 & 27 & 27 & 46 & 1.98 \\
\hline Average & & 5.71 & 33 & 19 & 32 & 16 & 52 & 1.83 \\
\hline
\end{tabular}

Abbreviations: NSO - nitrogen, sulfur, oxygen; HCs - hydrocarbons; Sat - saturated; Aro - aromatic.

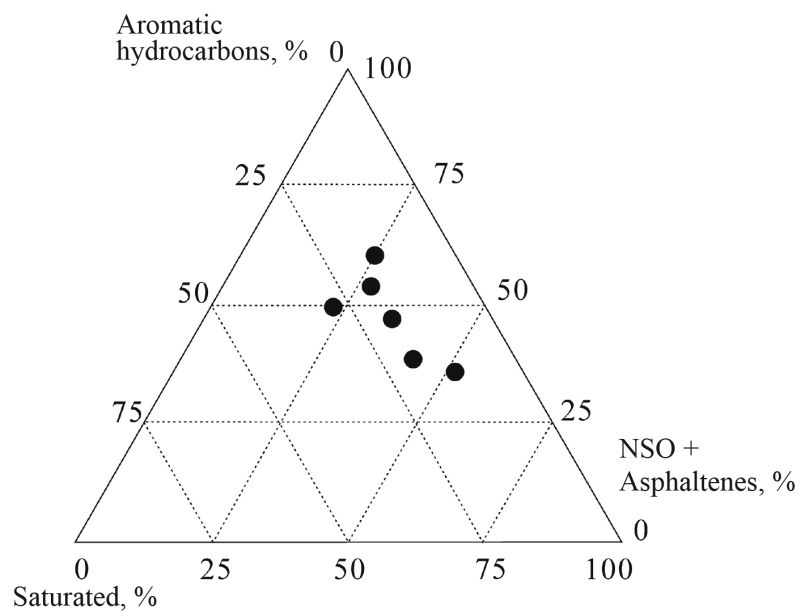

Fig. 2. Ternary diagram of the extracted samples showing the relative proportions of saturated, aromatic and NSO components. 


\subsubsection{Molecular composition of hydrocarbons}

The distribution of n-alkanes and biomarkers was determined by GC-MS (Table 2, Fig. 3). The n-alkanes in oil shale samples include a set of saturated n-alkanes and isoprenoids [19-23]. The distribution of n-alkanes shows that low- to medium-molecular-weight compounds $\left(n-C_{13}-n-C_{23}\right)$ are dominant, and there is a significant amount of waxy alkanes $\left(+n-C_{23}\right)$ that are similar to long-chain alkanes present in algae and bacteria [22] (Fig. 3).

The acyclic isoprenoids pristine $(\mathrm{Pr})$ and phytane $(\mathrm{Ph})$ were found in all samples (Fig. 3). The $\mathrm{Pr} / \mathrm{Ph}$ ratio has been widely used as a redox condition parameter in sedimentary environmental research [23]. Lijmbach [24] showed that $\mathrm{Pr} / \mathrm{Ph}$ ratios below 0.6 indicated anoxic conditions, ratios between 1.0 and 3.0 signified suboxic conditions and ratios above 3.0 suggested oxic conditions. For the six oil shale samples tested, the $\mathrm{Pr} / \mathrm{Ph}$ ratios range from 0.47 to 0.91 (average 0.7 ; Table 2.), pointing to suboxic conditions, which are conducive to the preservation of organic matter.

The relationship between $\mathrm{Pr} / \mathrm{n}-\mathrm{C}_{17}$ and $\mathrm{Ph} / \mathrm{n}-\mathrm{C}_{18}$ is often used to study the source of organic matter and the sedimentary paleoenvironment of source rocks [25-28]. This study found the $\mathrm{Pr} / \mathrm{n}-\mathrm{C} 17$ and $\mathrm{Ph} / \mathrm{n}-\mathrm{C} 18$ values to be in the range of $0.55-2.51$ (average 1.12) and 1.78-2.16 (average 1.79), respectively. The overall numerical fluctuation is relatively small, and the data indicate that the algal/microbial sources of organic matter were deposited under reducing conditions [29] (Fig. 4; Table 2).

Table 2. n-Alkanes to isoprenoids biomarker ratios

\begin{tabular}{|c|c|c|c|c|c|c|c|c|c|c|}
\hline \multirow[b]{2}{*}{ Sample } & \multirow[b]{2}{*}{$\begin{array}{c}\text { Depth, } \\
\text { m }\end{array}$} & \multirow[b]{2}{*}{ CPI } & \multirow[b]{2}{*}{$\mathrm{Pr} / \mathrm{Ph}$} & \multirow[b]{2}{*}{$\mathrm{Pr} / \mathrm{n}-\mathrm{C}_{17}$} & \multirow[b]{2}{*}{$\mathrm{Ph} / \mathrm{n}-\mathrm{C}_{18}$} & \multicolumn{4}{|c|}{ Regular steranes, m/z 217} & \multirow[b]{2}{*}{ GI } \\
\hline & & & & & & 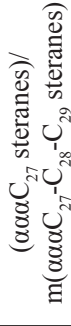 & 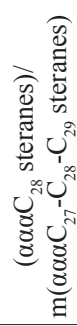 & 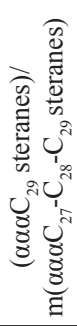 & $\underbrace{U^{2}}_{U^{2}}$ & \\
\hline NAO-1 & 45 & 1.56 & 0.47 & 0.55 & 1.78 & 0.24 & 0.18 & 0.59 & 0.4 & 0.15 \\
\hline NAO-2 & 52 & 1.51 & 0.91 & 2.51 & 2.16 & 0.41 & 0.18 & 0.41 & 1.02 & 0.18 \\
\hline NAO-3 & 66 & 1.77 & 0.65 & 1.3 & 1.48 & 0.35 & 0.18 & 0.46 & 0.76 & 0.23 \\
\hline NAO-4 & 73 & 1.34 & 0.55 & 0.96 & 1.26 & 0.38 & 0.15 & 0.47 & 0.81 & 0.31 \\
\hline NAO-5 & 79 & 1.66 & 0.85 & 0.62 & 1.97 & 0.29 & 0.23 & 0.47 & 0.62 & 0.27 \\
\hline NAO-6 & 92 & 1.99 & 0.75 & 0.78 & 2.07 & 0.32 & 0.19 & 0.48 & 0.67 & 0.29 \\
\hline Average & & 1.64 & 0.7 & 1.12 & 1.79 & 0.33 & 0.18 & 0.48 & 0.69 & 0.24 \\
\hline
\end{tabular}

Abbreviation: CPI - carbon preference index. 


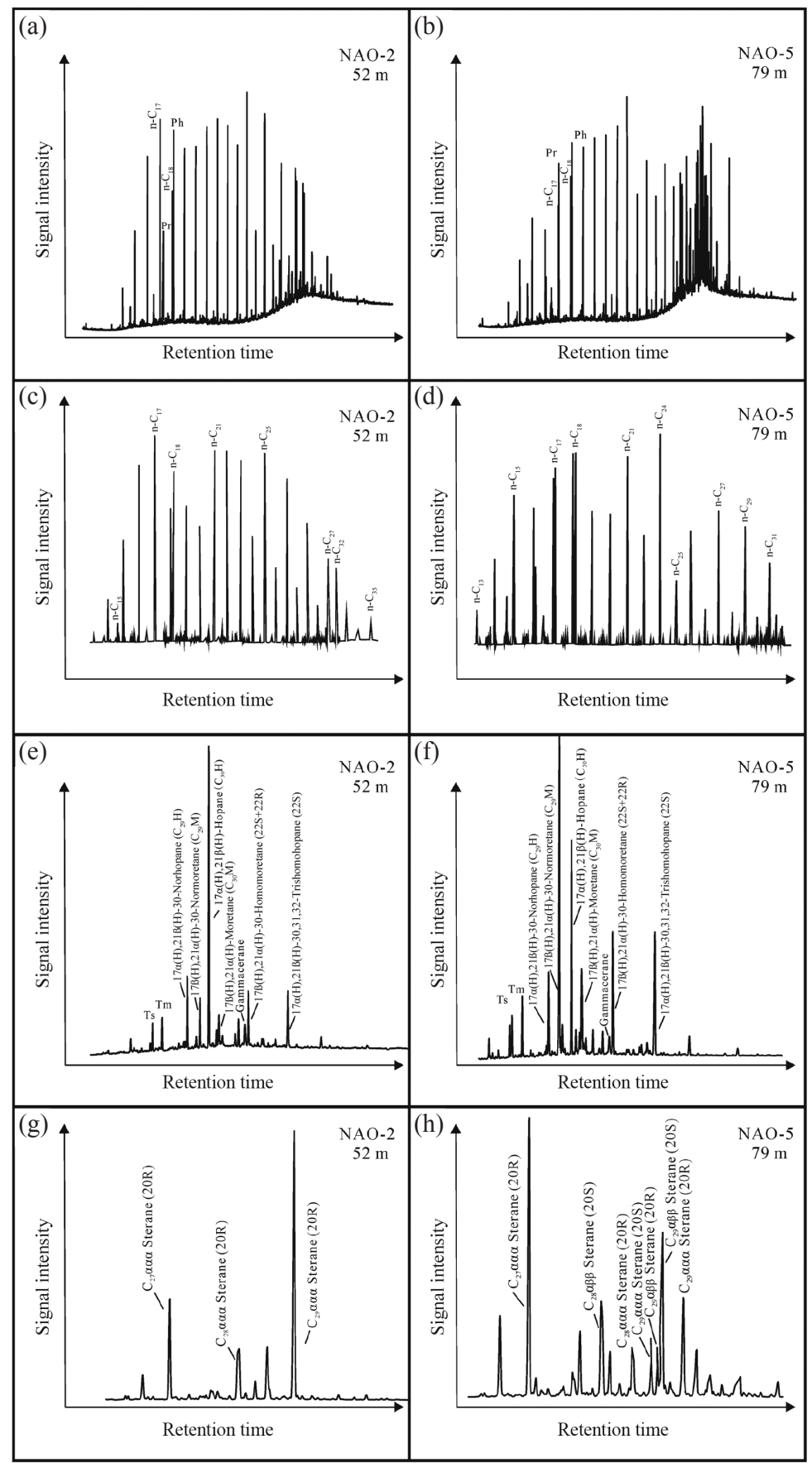

Fig. 3. (a-b) Gas chromatograms-mass chromatograms (TIC); (c-d) m/z 85 mass chromatogram of saturated hydrocarbons; (e-f) m/z 191 mass chromatogram of saturated hydrocarbons; (g-h) m/z 217 mass chromatogram of oil extracted from oil shale of member 1 of the Nenjiang Formation. 


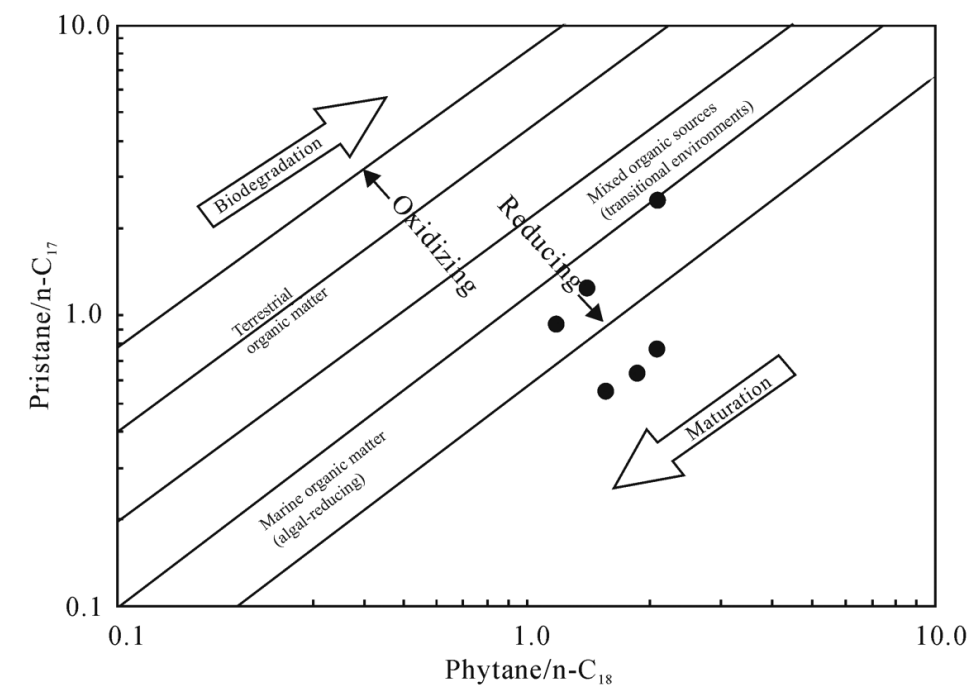

Fig. 4. Cross correlation between $\mathrm{Pr} / \mathrm{n}-\mathrm{C}_{17}$ and $\mathrm{Ph} / \mathrm{n}-\mathrm{C}_{18}$ ratios [27, 28].

The m/z 217 mass chromatogram of saturated hydrocarbons in the oil shale samples shows the different distribution of diasteranes and steroids. Among these compounds are conventional steroids $\mathrm{C}_{27}, \mathrm{C}_{28}$ and $\mathrm{C}_{29}$, which are related to the organic matter source materials (Fig. 3; Table 2).

A study by Huang and Meinschein [30] established that the conventional steroids $\mathrm{C}_{27}, \mathrm{C}_{28}$ and $\mathrm{C}_{29}$ were all specific to different sources of organic matter, and their relative proportions could be used to study the contribution of various types of the matter (Fig. 5). The relative proportions of steroids $\mathrm{C}_{27}$, $\mathrm{C}_{28}$ and $\mathrm{C}_{29}$ in the Nenjiang Formation oil shale samples were calculated to be the following: $\mathrm{C}_{29} 41-59 \%$, average $48 \%$; $\mathrm{C}_{28} 12-23 \%$, average $18 \%$; and $\mathrm{C}_{27} 24-41 \%$, average $33 \%$ (Table 2; Fig. 3). Previous studies have established that $\mathrm{C}_{27}$ steroids are sourced from zooplankton and red algae, $\mathrm{C}_{28}$ steroids originate from diatoms, green algae and higher plants, and $\mathrm{C}_{29}$ steroids are derived from higher plants, some brown algae and green algae [30, 31]. Based on the relative contents of $\mathrm{C}_{27}, \mathrm{C}_{28}$ and $\mathrm{C}_{29}$ steroids, it is speculated that the samples in this study predominantly originate from plankton and higher plants and may be mixed with some marine organic matter.

Gammacerane was initially considered a high salinity indicator [32], and it is also thought to be related to the increase in salinity in marine and lacustrine environments [23, 33] (Fig. 6). The gammacerane index (GI, gammacerane/ $\alpha \beta-\mathrm{C}_{30}$ hopane) of the extracted samples reflects a high salinity, reducing environment [34] (Fig. 3; Table 2).

The TS content in the oil shale samples studied is positively correlated with GI values. The Nenjiang Formation oil shale samples are characterized by high sulfur contents, low TOC/TS ratios and high GI values, which suggests the high water column salinity and sulfate concentration in the oil shale 


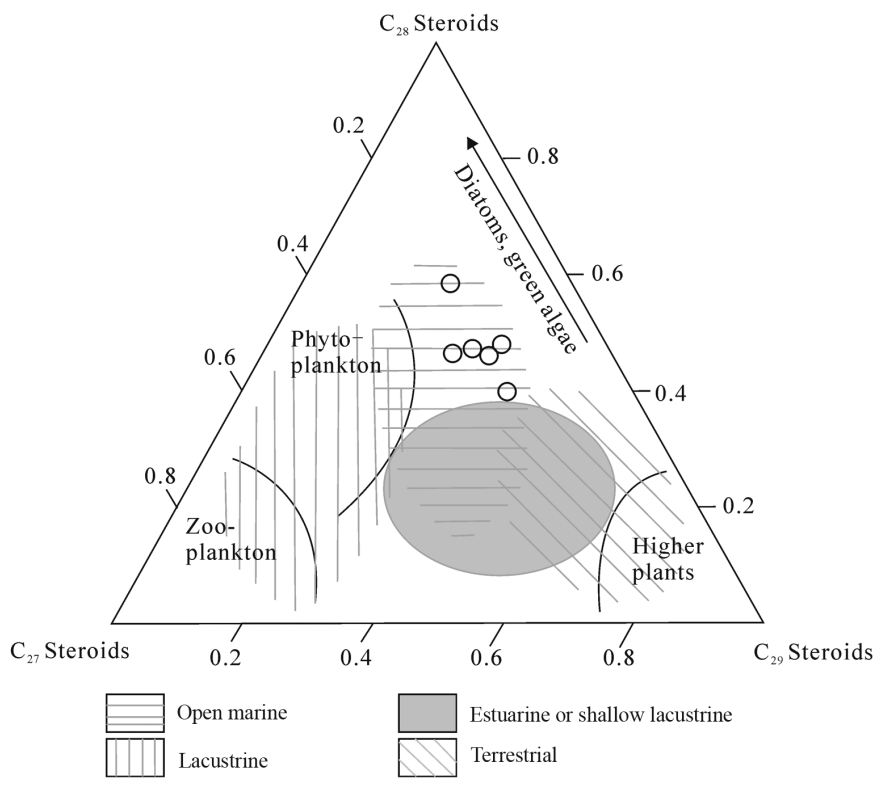

Fig. 5. Ternary diagram of the relative proportions of steroids $\mathrm{C}_{27}, \mathrm{C}_{28}$ and $\mathrm{C}_{29}$ (relationship between organic matter input and depositional environment).

sedimentary environment. Based on the sedimentary facies characteristics of the Nenjiang Formation, it is likely that in the period of oil shale deposition, short-term seawater intrusion into the lake basin led to water stratification, forming a closed anoxic environment at the bottom of the basin with high salt and gammacerane contents (Fig. 1). In the later stage of oil shale deposition, the seawater channel entering the lake basin was closed, and the salinity of the closed anoxic environment at the bottom of the lake decreased slowly.

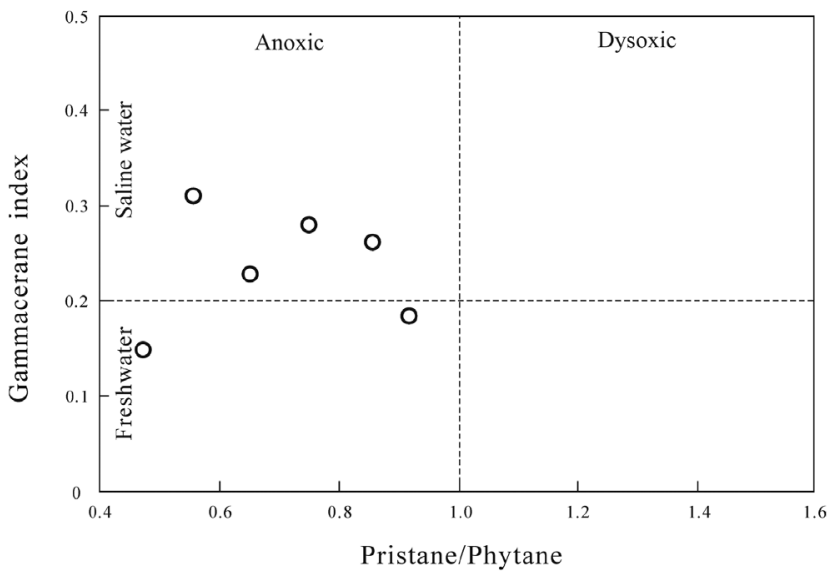

Fig. 6. Plot of gammacerane index and Pristane/Phytane of the extracted oil samples [23]. 


\subsubsection{Hydrocarbon monomer carbon isotopic composition}

The carbon isotopic compositions (CIC) of n-alkanes, $\mathrm{Pr}$ and $\mathrm{Ph}$ in the oil shale samples from the Nenjiang Formation are plotted in Figure 7 and presented in Table 3. The carbon isotopic composition of hydrocarbon monomers can reflect the source and composition of organic matter in sediments [35]. The CIC of hydrocarbon monomers in the oil shale samples studied was between -30.7 and $-26.4 \%$. It has been thought that the organic matter in lacustrine sediments is a mixture of sapropelic and humic components. The carbon isotope distribution curve of n-alkanes in lacustrine organic matter generally increases with increasing carbon number $[35,36]$.

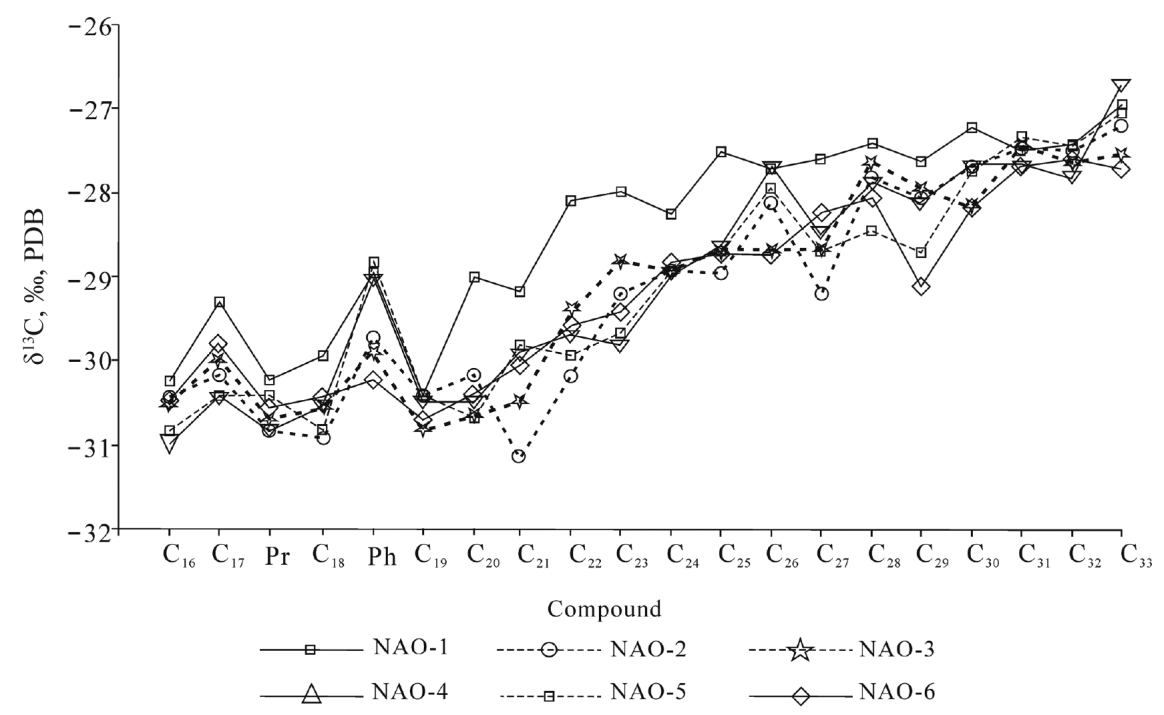

Fig. 7. Carbon isotopic composition of n-alkanes, pristane and phytane in saturated hydrocarbons.

The carbon isotope distribution of n-alkanes has no obvious change from $n-C_{16}$ to $n-C_{23}$. After $n-C_{23}$, the n-alkanes gradually become heavier with increasing carbon number, indicating that the sources of high-carbon and lowcarbon organic matter are similar, mainly the input of lake organic matter, and the input of higher plants accounts for a relatively small proportion.

\subsection{Total organic carbon and organic carbon isotopes}

The test results show that $\delta^{13} \mathrm{C}_{\text {org }}$ in oil shale is from -26 to $-33 \%$, and the TOC content varies between 0.29 and $6.18 \%$. The changes in TOC and $\delta^{13} \mathrm{C}_{\text {org }}$ give evidence of obvious stratigraphic characteristics. From the bottom to the middle of member 1 of the Nenjiang Formation, $\delta^{13} \mathrm{C}_{\text {org }}$ suggests an obvious negative migration with a negative migration range of $6 \%$, and the TOC of 
Table 3. Carbon isotopic composition of $\mathrm{n}$-alkanes, $\mathrm{Pr}$ and $\mathrm{Ph}$ in saturated hydrocarbons

\begin{tabular}{|l|c|c|c|c|c|c|c|c|c|c|}
\hline Sample & $\begin{array}{c}\text { Depth, } \\
\mathrm{m}\end{array}$ & $\mathrm{n}^{-\mathrm{C}_{16}}$ & $\mathrm{n}-\mathrm{C}_{17}$ & $\mathrm{Pr}$ & $\mathrm{n}^{-C_{18}}$ & $\mathrm{Ph}$ & $\mathrm{n}-\mathrm{C}_{19}$ & $\mathrm{n}-\mathrm{C}_{20}$ & $\mathrm{n}-\mathrm{C}_{21}$ & $\mathrm{n}^{-\mathrm{C}_{22}}$ \\
\hline NAO-1 & 45 & -30.4 & -29.5 & -30.4 & -30.1 & -29.2 & -30.6 & -29.2 & -29.4 & -28.3 \\
NAO-2 & 52 & -30.1 & -29.8 & -30.5 & -30.6 & -29.4 & -30.1 & -29.8 & -30.8 & -29.8 \\
NAO-3 & 58 & -30.2 & -29.7 & -30.4 & -30.3 & -29.6 & -30.5 & -30.4 & -30.2 & -29.1 \\
NAO-4 & 66 & -30.7 & -30.1 & -30.5 & -30.2 & -28.7 & -30.2 & -30.2 & -29.6 & -29.4 \\
NAO-5 & 73 & -30.5 & -30.1 & -30.1 & -30.5 & -28.5 & -30.1 & -30.4 & -29.5 & -29.6 \\
NAO-6 & 79 & -30.2 & -29.5 & -30.2 & -30.1 & -29.9 & -30.4 & -30.1 & -29.7 & -29.3 \\
\hline
\end{tabular}

the corresponding formation indicates a positive migration with a range of $5 \%$. At the top of member 1 , there is a positive deviation in $\mathrm{TOC}$ and $\delta^{13} \mathrm{C}_{\text {org }}$ contents. Specifically, the average $\delta^{13} \mathrm{C}_{\text {org }}$ content is $-27.6 \%$, and the average TOC content is $0.38 \%$. At depths of $48-110 \mathrm{~m}$, the $\delta^{13} \mathrm{C}_{\text {org }}$ averages $-29.9 \%$ and TOC averages $3.35 \%$. At depths of $10 \mathrm{~m}-48 \mathrm{~m}$, the respective average figures are $-26.8 \%$ and $1.94 \%$ (Fig. 8 ; Table 4 ).

Previous studies believed the $\mathrm{CO}_{2}$ concentration fluctuations during the Cretaceous OAE3 period to be related to extensive volcanic activity and resulted in a series of biogeochemical events [1, 5-7]. Quan et al. [37] quantitatively restored the atmospheric $\mathrm{CO}_{2}$ concentration near the $\mathrm{S}-\mathrm{C}$ boundary of the Late Cretaceous, based on the stomatal characteristics of the fern-type Ginkgo biloba cuticle in the Zijiayin Basin. The researchers showed that the concentration of $\mathrm{CO}_{2}$ increased from $531 \mathrm{ppm}$ in the Santonian to $624 \mathrm{ppm}$ in the S-C boundary and then decreased to $558 \mathrm{ppm}$ in the Late Campanian, indicating that it peaked near the $\mathrm{S}-\mathrm{C}$ boundary. The soil-forming carbonate may also prove useful in restoring paleo- $\mathrm{CO}_{2}$ concentrations [38]. Hong and Lee [39] restored the $\delta^{13} \mathrm{C}_{\text {org }}$ content of the soil-forming carbonate in the Gyeongsang Basin, Korea, using the paleobarometer model. The results obtained by Quan et al. [37] and Taijka [40] revealed that the concentration of $\mathrm{pCO}_{2}$ decreased significantly from the $\mathrm{S}-\mathrm{C}$ boundary to the Early Campanian. In addition, Hong and Lee [39] determined that during the Cretaceous, the change in $\mathrm{CO}_{2}$ concentration in the atmosphere was related to the change in paleotemperature.

With increasing atmospheric $\mathrm{pCO}_{2}$, the mass of ${ }^{12} \mathrm{C}$ and ${ }^{13} \mathrm{C}$ in dissolved inorganic salts in water will also increase. This process disrupts the original ${ }^{13} \mathrm{C}$ equilibrium between calcium carbonate and $\mathrm{CH}_{2} \mathrm{O}$, and the carbon isotope fractionation value will change significantly [41]. With increasing atmospheric $\mathrm{pCO}_{2}$, the content of dissolved $\mathrm{CO}_{2}$ in the lake basin also increased gradually, and ${ }^{13} \mathrm{C}$ in $\mathrm{CH}_{2} \mathrm{O}$ produced by photosynthesis was consumed in large amounts. Therefore, the increase in atmospheric $\mathrm{CO}_{2}$ concentration during the $\mathrm{S}-\mathrm{C}$ 
Table 3 (continued)

\begin{tabular}{|l|r|r|r|r|r|r|r|r|r|r|}
\hline $\mathrm{n}-\mathrm{C}_{23}$ & $\mathrm{n}-\mathrm{C}_{24}$ & $\mathrm{n}-\mathrm{C}_{25}$ & $\mathrm{n}-\mathrm{C}_{26}$ & $\mathrm{n}-\mathrm{C}_{27}$ & $\mathrm{n}-\mathrm{C}_{28}$ & $\mathrm{n}-\mathrm{C}_{29}$ & $\mathrm{n}-\mathrm{C}_{30}$ & $\mathrm{n}-\mathrm{C}_{31}$ & $\mathrm{n}-\mathrm{C}_{32}$ & $\mathrm{n}-\mathrm{C}_{33}$ \\
\hline-28.2 & -28.4 & -27.7 & -27.9 & -27.8 & -27.6 & -27.8 & -27.4 & -27.7 & -27.6 & -27.1 \\
-28.9 & -28.6 & -28.6 & -27.8 & -28.9 & -27.5 & -27.8 & -27.4 & -27.2 & -27.2 & -26.8 \\
-28.5 & -28.6 & -28.4 & -28.4 & -28.4 & -27.4 & -27.6 & -27.8 & -27.1 & -27.3 & -27.2 \\
-29.5 & -28.7 & -28.3 & -27.4 & -28.2 & -27.6 & -27.8 & -27.3 & -27.3 & -27.5 & -26.4 \\
-29.4 & -28.6 & -28.4 & -27.6 & -28.4 & -28.1 & -28.4 & -27.4 & -27 & -27.1 & -26.7 \\
-29.1 & -28.5 & -28.4 & -28.4 & -27.9 & -27.8 & -28.8 & -27.9 & -27.4 & -27.3 & -27.4 \\
\hline
\end{tabular}

boundary period may be the main reason for the increase in TOC content and the negative deviation in $\delta^{13} \mathrm{C}_{\text {org }}$ content in sediments.

The greenhouse climate conditions in the OAE3 period were warm and humid paleoclimate conditions [1]. Studying the climate fluctuation in the Bering Strait during the Cretaceous period through examination of $\delta^{18} \mathrm{O}$ change and flora distribution, Tajika [40] showed that the climate in the Santonian-Early Campanian period was relatively warm. Previously it has

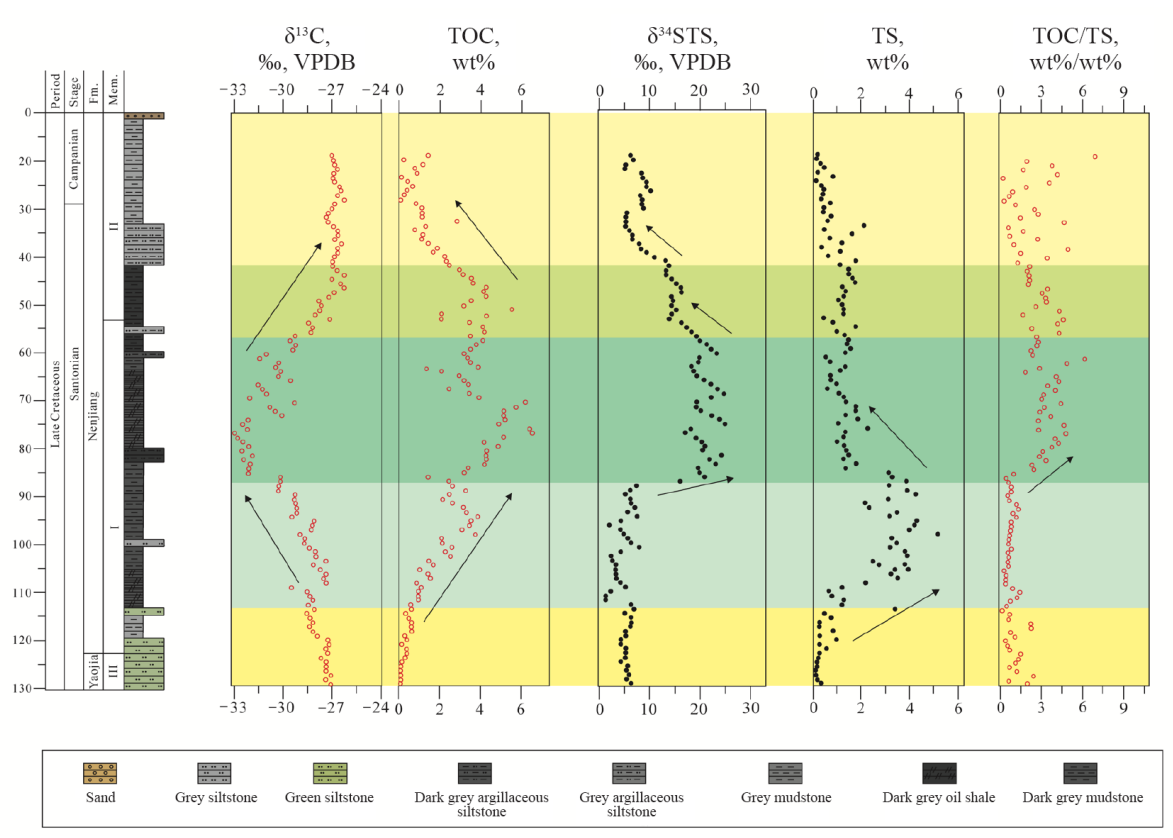

Fig. 8. Geochemical stratigraphic histogram of oil shale in well NA-1 of the Nenjiang Formation. (Abbreviations: Fm. - Formation, Mem. - Member.) 


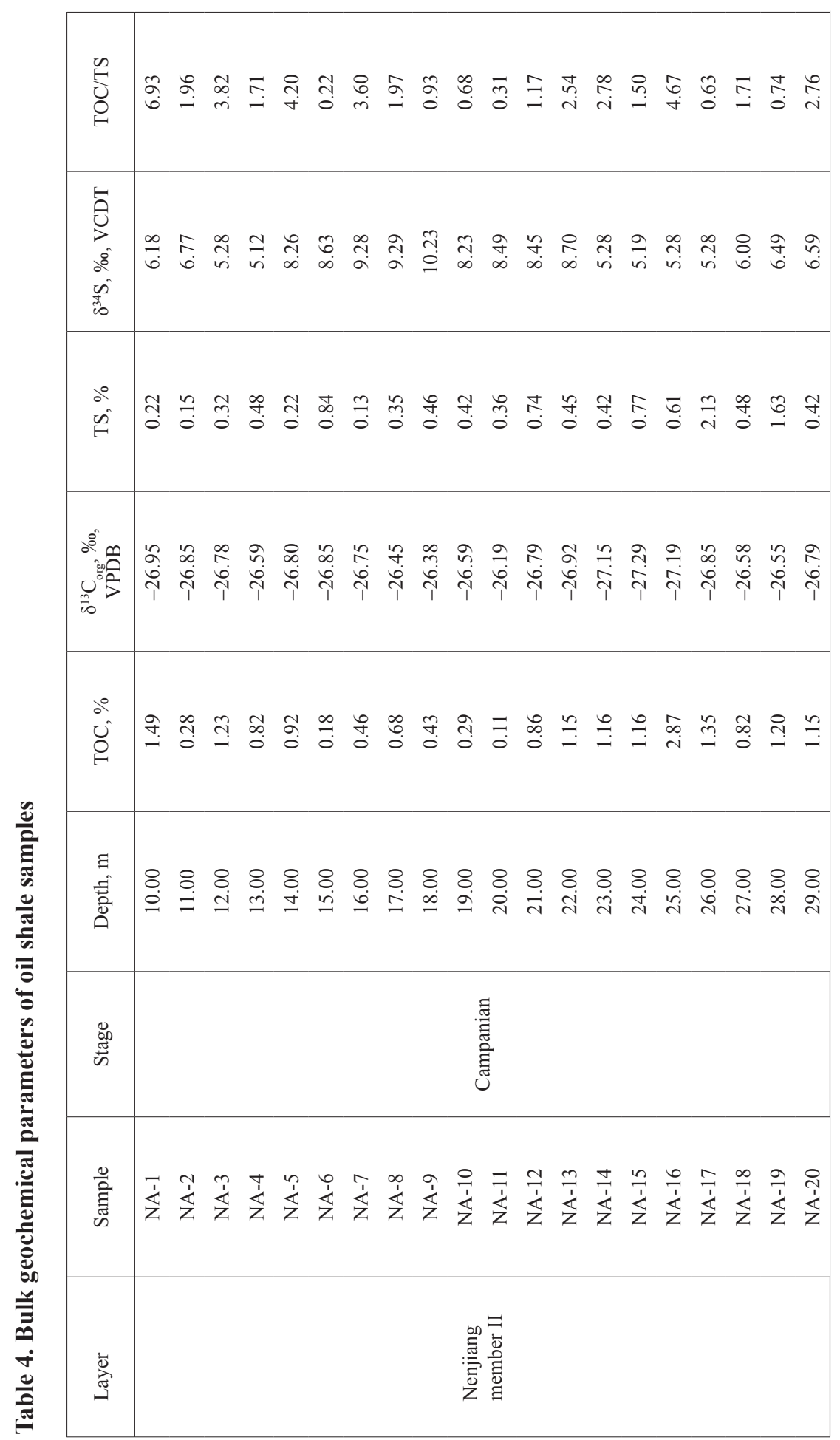




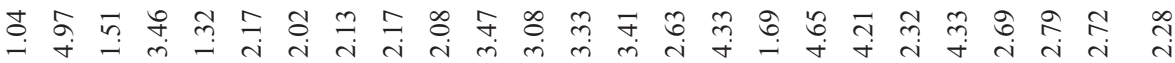

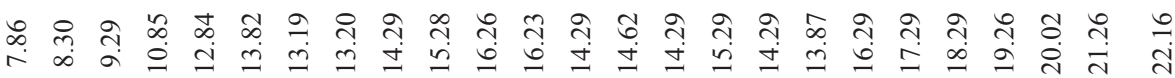
ঙํ

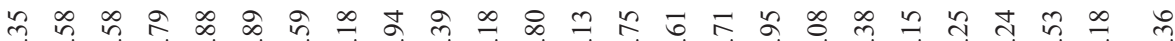

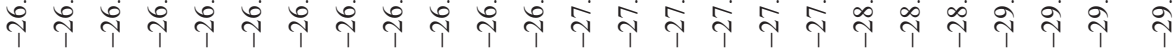

サ.

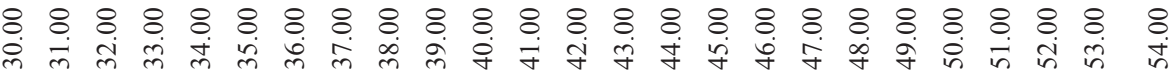




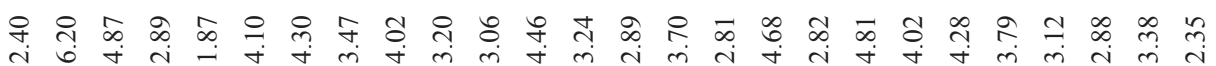

ஸิ $\infty$ ก ก

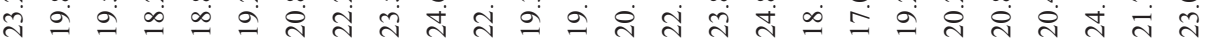

ஸे

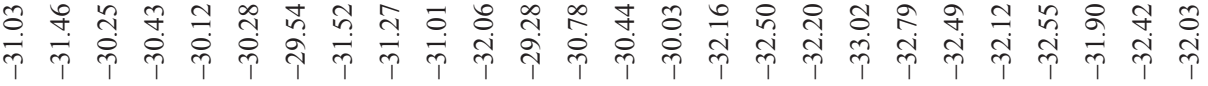

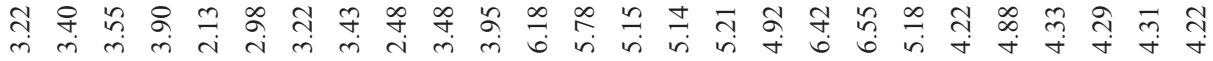

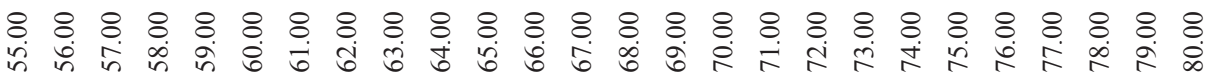

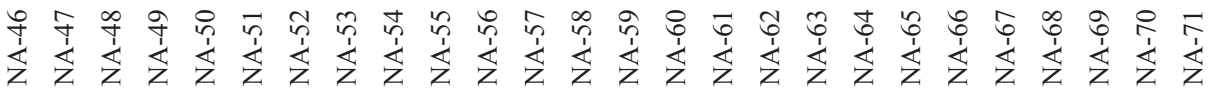




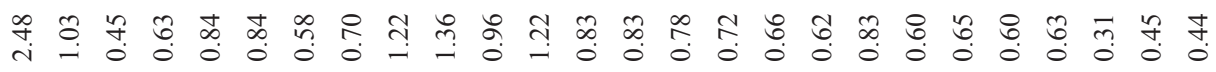

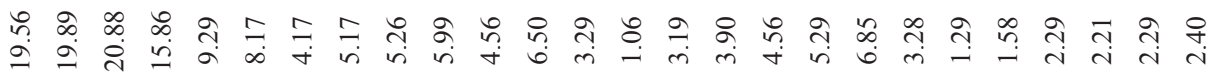

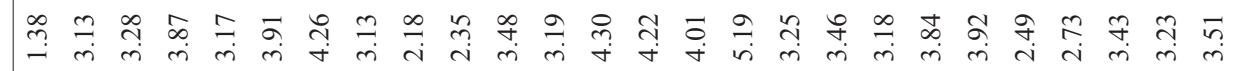

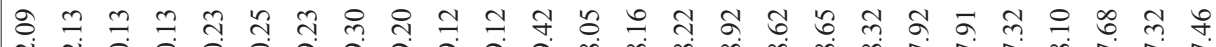

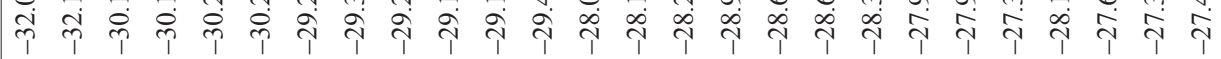

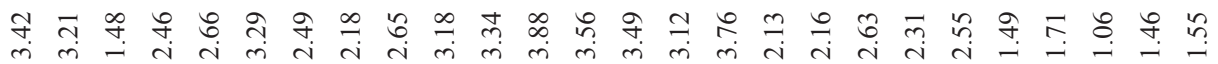

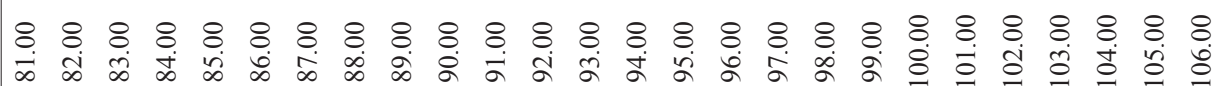

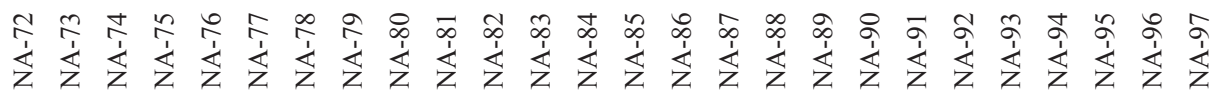




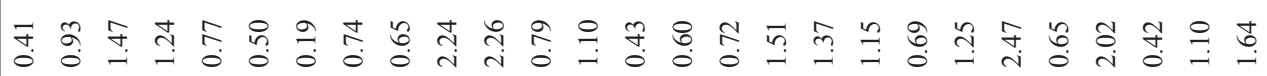

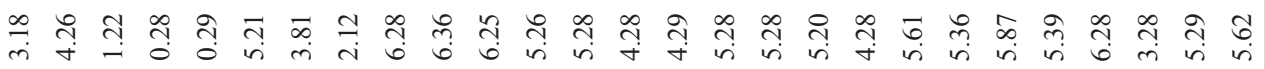

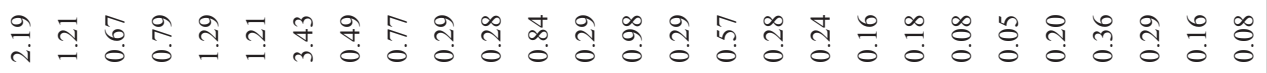

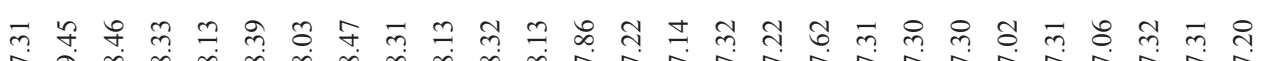

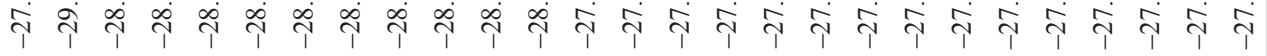

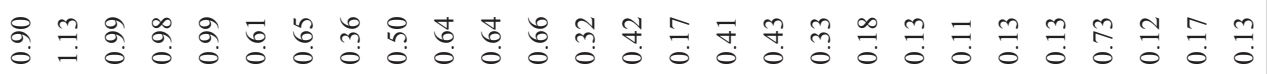
\& \& \& \& \& \& \& \& \& \& \& \& \& \& \& \& \& \& \& \& \& \& \& \& \& \&

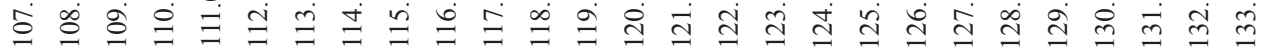


been established that plants exchange water and gas with air through leaf stomata to control the carbon isotope value of the organic matter produced by them [39]. Under humid climate conditions, the leaves of terrestrial plants open their stomata and increase the number of stomata to absorb more water, and the carbon isotope fractionation in the organic matter produced by plant photosynthesis will expand, resulting in a negative $\delta^{13} \mathrm{C}_{\text {org }}$ value [39]. Yan [41] believes that near the boundary period of the first and second segments of the Nenjiang Formation the humidity was relatively high, and then the climate gradually became dry. Therefore, the researcher concludes that the warm and humid paleoclimate may have been the main mechanism of the negative $\delta^{13} \mathrm{C}_{\text {org }}$ deviation near the $\mathrm{S}-\mathrm{C}$ boundary [41].

\section{4. Total sulfur and total sulfur isotope contents}

The total sulfur isotope and TS contents of oil shale fluctuate with formation change but not similarly. The average content of the total sulfur isotope in oil shale is $6.07 \%$ at depths of $133-85 \mathrm{~m}$, and a large, sudden positive deviation occurs at $85 \mathrm{~m}$, with an approximate amplitude of 20\%. The average sulfur isotope content of the $85-45 \mathrm{~m}$ oil shale is $20.02 \%$, the highest value being $24.16 \%$ at $78 \mathrm{~m}$. The total sulfur isotope content of the $45-10 \mathrm{~m}$ oil shale gradually declines to $7.32 \%$ at $32 \mathrm{~m}$ (Fig. 8; Table 4) [42].

The reducing bacteria in the sediment can promote the reaction of its organic matter with sulfate to generate hydrogen sulfide gas $\left(\mathrm{H}_{2} \mathrm{~S}\right)$. The generated hydrogen sulfide and iron oxide or iron ions in the formation continue to react to form pyrite. This entire process is called microbial sulfate reduction (MSR). By simulating the MSR reaction process under experimental conditions, it was found that sulfur isotopes in sulfides could generate up to $70 \%$ o fractionation and produce large amounts of pyrite [43]. The principle of the MSR reaction discloses that the production of pyrite is mainly controlled by the sulfate concentration, organic matter abundance and dissolved iron concentration in the aqueous and sedimentary environment. The most favourable environment for large-scale pyrite production is an anaerobic environment rich in highconcentration organic carbon and sulfate. Previous related studies have shown that sulfate reduction reactions usually occur below the interface between sediments and seawater in the seafloor environment, and the bottom layer of seawater forms a sulfate-rich and reducing environment. At the sedimentwater interface, the MSR reaction occurs to form pyrite, which results in a significant reduction in TOC/TS in the sediment. The TOC/TS ratio less than 1 indicates that there is a sulfide reduction environment in sediment pores that are rich in organic deposits [44-50]. In the lake environment, the supply of iron and the productivity of organic matter are usually higher than those in the marine environment [51]. Therefore, the sulfate content is the most significant factor restricting MSR, so the TOC/TS ratio of terrestrial sediment is relatively high, and researchers typically used TOC/TS as a reference to 
identify seawater and non-seawater environments [46, 47]. In modern marine sediments, the TOC/TS is $2.8+0.8$, with an average of approximately 3 [46].

The TOC/TS ratios at the top of the Yaojia Formation and in the lower part of the Nenjiang Formation $(117-83 \mathrm{~m}$ ) are low, mostly less than 1, which is consistent with the typical vulcanization environment in the modern Black Sea. This reveals that the vulcanization environment of pore water or deep water may be related to transgression at this stage $[41,52]$. The middle part of member $1(80-33 \mathrm{~m})$ was determined to have been in a normal marine environment, and the average sulfur content in the samples is $1.28 \%$, which is higher than the average sulfur content in modern lake sediments, indicating that there was a high sulfate concentration in the lake water at that time. Higher concentrations of sulfate are needed in high-salinity water environments [46]. The sediments of the Songliao Basin are obvious lacustrine facies, so it is considered that the sedimentary conditions of this stage were those of a brackish water-saline water environment. The identification of biomarkers such as gammacerane also indicates the existence of a marine saline water environment. The TOC/TS ratio in the upper part of member 2 restores a low value at $32 \mathrm{~m}$. At the same time, sulfur isotope fractionation did not change significantly at this stage, indicating that the sulfur cycle did not fluctuate much. Studies on biomarker compounds of upper mudstones in member 1 showed that the water body in the Songliao Basin was apparently desalinated after the Santonian-Campanian boundary. Organic geochemical evidence of a high $\mathrm{Pr} / \mathrm{Ph}$ ratio and a low GI suggest low salinity and high biological productivity in the water environment in the upper part of member $2[42,53]$. The TOC/TS ratio may have decreased due to the oxidation of organic matter with decreasing depth. The top strata of the Nenjiang Formation are mainly composed of coarse silty mudstone and sandstone. The TOC and TS contents in these strata are relatively low and TOC/TS relatively high. Although some samples exhibit TOC/TS $<1$, they are not of indicative significance to the sedimentary environment due to the change in provenance [16], which may be a response to the change in the provenance of coarse-grained silicate sediments (Fig. 8, Fig. 9).

At the same time, by investigating the TOC contents in the Nenjiang Formation core, we can see that the TOC in member $1(87-57 \mathrm{~m})$ core can reach $6.55 \%$, averaging $4.04 \%$. According to the above analysis of oil shale deposits, a water environment with a high TOC content corresponds to a sulfidecontaining, high-salinity deep water layer. Seawater injection results in salinity stratification of seawater, and the reducing environment in the bottom water body is conducive to the accumulation and preservation of organic matter.

A recent study by Brunner and Bernasconi [43] showed that during the reduction of sulfur in the sulfur cycle pathway the direction and scale of kinetic sulfur isotope fractionation under sulfate reduction were directly related to extracellular sulfate concentration. Experiments carried out by the researchers demonstrated that fractionation could reach $66 \%$ at high sulfate 


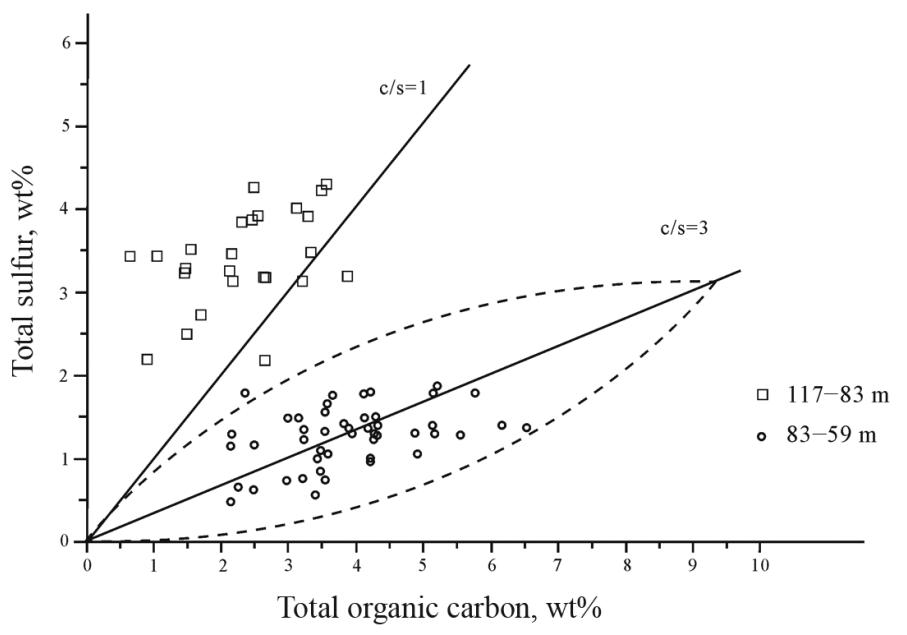

Fig. 9. Relationship between total organic carbon and total sulfur.

concentrations [43]. At very low TS concentrations, $<200 \mu \mathrm{M}$, sulfur isotope fractionation was significantly inhibited [54]. A recent study by Canfield and Tharndrup [55] on vulcanization systems showed that sulfate-reducing bacteria in independent natural communities could produce large kinetic fractionation under vulcanization conditions. The disproportionation reaction could obviously increase the fractionation during the sulfate reduction reaction, which could lead to the value of fractionation between reactant sulfate and product sulfide exceeding 70\% [55].

In lacustrine systems, sulfates are usually derived from weathering of continental rocks, including the oxidation of pyrite and dissolution of evaporite. The sulfate isotope values of evaporite dissolution (mainly gypsum) usually range from +10 to $+30 \%$, and the sulfate isotope values of iron oxide sources are mostly between -40 and $+5 \%$ o [55]. The sulfate abundance of lacustrine systems is generally $10-500 \mu \mathrm{M}$, but it can reach $2 \mathrm{mM}$ or higher under the special conditions of a river environment in some evaporite-enriched sedimentary rocks [56]. Although evaporite sedimentary strata developed in the Quantou Formation of the Songliao Basin, the background value of $\delta^{34} \mathrm{~S}$ in Nenjiang Formation lakes is approximately $+5 \%$. It is obvious that sulfate in lake water does not originate from evaporite but mainly from pyrite oxide imported from land. At the same time, the dissolved evaporite with a higher isotope value than that of pyrite oxide may not be the main cause of the negative sulfur isotope deviation in the Nenjiang Formation.

The negative deviation in pyrite $\delta^{34} \mathrm{~S}$ in oil shale at the bottom of the Nenjiang Formation (114-87 m) may have been due to the increase in sulfate concentration in the lake basin, which led to an increase in the sulfate reduction rate and the enhancement of microbial sulfur disproportionation. 
The contents of pyrite and organic matter at the bottom of member 1 are very high, which indicates that high nutrient contents accelerate the sulfate reduction rate and increase pyrite deposition. The stratified water-sediment interface is the main place for sulfur metabolism and provides good conditions for disproportionation. Although the existence of gammacerane in member 1 of the Nenjiang Formation is a strong evidence of water stratification [12], it may lead to a negative deviation of $\delta^{34} \mathrm{~S}$ through disproportionation. However, its fractionation value is far from the expected value of disproportionation, which is more than $45 \%$. The concentration of sulfate in modern seawater is $10-15 \mathrm{Mm}$, but in lake water it is only $10-500 \mu \mathrm{m}[46,47]$. The transgression event at the bottom of member 1 could have introduced a high concentration of sulfate into the lake basin and rapidly expanded the lake sulfate reservoir. In the process of kinetic isotope fractionation, the sulfate concentration (starting material) in lake water rapidly increased, and the reaction speed of MSR also accelerated, which will expand the sulfur fractionation between sulfate and pyrite and lead to the negative deviation of sulfur isotopes in pyrite. With increasing sulfate concentration, that of sulfides will increase and accumulate in pore or deep water through sulfate reduction reactions. Pyrite can be formed if ferrous ions are abundant enough on the surface of minerals. For example, in the deep anaerobic Black Sea, high concentrations of dissolved sulfides cause large amounts of pyrite to form in water columns and accumulate in sediments such as rain [47, 57-59]. Therefore, the increase in sulfate concentration caused by transgression is the best explanation for the negative sulfur isotope bias, palaeontological evidence and biomarker compound evidence in member 1 of the Nenjiang Formation [60].

During the formation of oil shale in the middle part of member $1(87-57 \mathrm{~m})$, the lake basin was isolated from seawater due to a decrease in sea level, and the connection between the lake basin and seawater was gradually closed. The influence of transgression on sediments gradually weakened, and the concentration of sulfate in lake water decreased with the rapid distillation of sulfate. At the same time, sulfate reduction led to a decrease in sulfate content and the occurrence of pyrite burial [60-62]. Although the TS content of oil shale in the corresponding formation is reduced, it is still relatively high. When pyrite burial results in a low sulfate concentration, sulfur isotope fractionation will decrease, and residual sulfate and sulfide will produce a positive deviation in $\delta^{34} \mathrm{~S}$. The sulfur isotope value of pyrite in the middle of member 1 exhibits a positive deviation of $+23 \%$.

The TS of evaporite in member 3 of the Quantou Formation has been previously tested by other researchers. The $\delta^{34} \mathrm{~S}$ value varies from +8.1 to $+13.2 \%$, with an average of approximately $+10 \%$. These results may represent the background value of sulfate $\delta^{34} \mathrm{~S}$ in lake water [63]. During the Cretaceous, the average value of sulfate $\delta^{34} \mathrm{~S}$ in seawater was $+19 \%$ [51-61]. This transgression process inevitably increased the original sulfate $\delta^{34} S$ value of lake water. However, even if the sulfate in lake water is completely replaced by 
seawater sulfate, the recorded peak sulfur isotope value of sedimentary pyrite did not exceed $+19 \%$. Sulfide is the product of MSR. Under the conditions of the mass balance fractionation law and kinetic isotope fractionation, $\mathrm{SO}_{4}^{2-}$, with a relatively weak $\mathrm{O}-\mathrm{S}$ bond, is preferentially used as energy in MSR. Even if the sulfur isotope fractionation value of sulfate is 0 , that of sulfide cannot be higher.

It is believed that the positive deviation of sulfur isotope fractionation is due to the heterogeneity of the composition of water. In an area isolated from sulfate in a water body, the sulfate concentration is very low, and that of organic matter is enriched. There may be a minimum sulfate concentration area in anaerobic water bodies, and in this region, Rayleigh fractionation of sulfate results in a further reduction in its concentration, and the residual sulfate of heavier $\delta^{34} \mathrm{~S}$ may be the source of sulfate in pore water. Superheavy pyrite would likely not form in the lowest sulfate zone and would form by the distillation of sulfate into the pores of sediment. This process is similar to that which caused the positive deviation in $\delta^{34} \mathrm{~S}$ in the OAEs of the Toarcian stage [63].

Subsequently, the input of weathered sulfate during the top deposition of member 1 interfered with the existence of the lowest sulfate zone, resulting in a high-sulfate-concentration and homogeneous environment overall [64, 65] (Fig. 8). From the upper to the middle part of member 2, the overall $\delta^{34} \mathrm{~S}$ in lake water declines steadily until the mid-Campanian period when the $\delta^{34} \mathrm{~S}$ returns to the background value. Because the sulfate reservoir is very small at this stage, the isotope records are more susceptible to local fluctuations, resulting in frequent changes in the depth and spatial distribution of $\delta^{34} \mathrm{~S}$. Therefore, this decline in overall $\delta^{34} \mathrm{~S}$ may be due to the increase in sulfate and nutrients caused by long-term continental weathering, which may be related to the high atmospheric $\mathrm{CO}_{2}$ concentration at this stage.

\subsection{Paleoenvironmental reconstruction}

The study of the Nenjiang Formation (83.7 Ma) in the Songliao Basin of the Cretaceous showed that OAE3 and transgression events might have led to the formation of oil shale with high oil potential [6]. During the depositional period of continental lacustrine sediments in depression basins, the atmospheric $\mathrm{CO}_{2}$ concentration persistently increased, and high-salinity seawater intruded into the basin due to the rise of the sea level. Then, the sea level decreased and seawater was isolated from the lake basin. Large quantities of organic matter-rich oil shales with marine characteristics were formed in this series of processes. A typical transgression model of a continental lake basin can be described as having four stages, based on the results of stable isotope, elemental content and biomarker determination in oil shale samples belonging to different stages (Fig. 10).

The first stage is characterized as follows. The lake water is shallow, and there is no density stratification. The organic matter content in lake sediments 


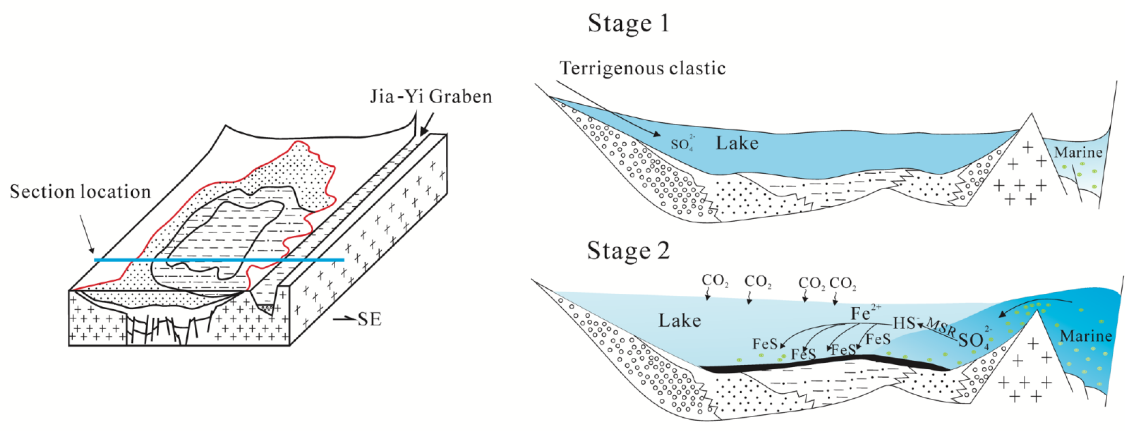

Stage 4

Stage 3

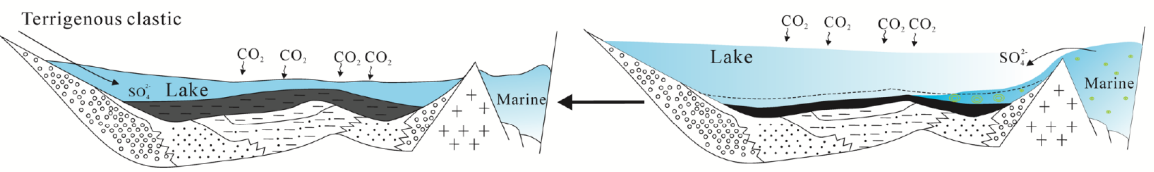

Fig. 10. Paleoenvironmental reconstruction of the Nenjiang Formation layer.

is low, which may be caused by the oxidative environment at the bottom of the lake basin. The mudstones formed during this period are mostly lightcoloured.

The second stage is described as follows. With rising sea level, seawater flows into the lake basin, which increases the salt concentration in the lake basin. Marine microorganisms also enter the lake basin with the seawater. The sulfate content in the lake water increases, the density of the water body is stratified obviously, and a sulfide layer is formed at the bottom, which leads to an increase in the sulfate reduction rate and the enhancement of sulfur disproportionation by microorganisms, resulting in the negative deviation in the pyrite $\delta^{34} \mathrm{~S}$ value, which is larger than the background value of the lake water. At the same time, due to the increase in atmospheric $\mathrm{CO}_{2}$ content, a large number of organisms in the lake basin produce and accumulate organic matter in the stratum.

The third stage consists in the following. Transgressions are weakened in this period. With decreasing sea level, currently, the water level in the lake basin is relatively high, and nutrients in the lake water are abundant. The organic matter content in the sediments of the lake bottom is also relatively high. The formation of pyrite reduces the concentration of sulfate in the lake basin, and the sulfur isotope fractionation value decreases. In an isolated area with sulfate in the water body, where the sulfate concentration is very low and organic matter is enriched, there may be a minimum sulfate concentration area in the middle of the anaerobic water body.

The fourth stage involves the following. The seawater is completely isolated from the lake basin The input of sulfate in weathered minerals 
destroys the existence of the lowest sulfate area in the lake basin resulting in a high-concentration and homogeneous sulfate environment overall.

\section{Conclusions}

Based on the systematic sampling, petrological observation and geochemical characteristics of oil shale from the Nenjiang Formation of NA-1 drilling in the Southeastern Uplift of the Songliao Basin, the following conclusions are drawn:

1. Through the observation of drilling cores it was found that the oil shale in the Nenjiang Formation mainly developed in members 1 and 2 of the formation. The lithology of oil shale is grey-black shale.

2. The oil shale is of high quality and has a high extractable organic matter content (2.73-9.25 mg/gTOC), highyield ofhydrocarbon fractions $(40-66 \%)$ and high saturated/aromatic hydrocarbons ratio.

3. The source material of the Nenjiang Formation oil shale is a mixture of aquatic organisms (algae and bacteria) and higher plants. Some geochemical parameters also indicate that the organic matter in the formation may include some marine organic matter. The organic matter in the Nenjiang Formation was deposited in a saline, reducing environment, which was conducive to the enrichment and preservation of the matter.

4. Under the influence of oceanic anoxic events $3, \mathrm{pCO}_{2}$ and the warm and humid paleoclimate caused an increase in the total organic carbon value and the $\delta^{13} \mathrm{C}_{\text {org }}$ negative deviation near the $\mathrm{S}-\mathrm{C}$ boundary.

5. Seawater entered the Songliao Lake Basin, and the nutrient composition, water density stratification and sulfate content increased. The reducing environment of the bottom water was conducive to the accumulation and burial of organic matter. With the increase in sulfate content, the total organic carbon/total sulfur value in the formation decreased, and the total sulfur isotope produced a negative bias.

6. Under the influence of oceanic anoxic events 3 and transgression events, the formation model of the Nenjiang Formation oil shale is complex and unique. Based on geochemical data, the paleoenvironment of the Nenjiang Formation oil shale formation is divided into four stages.

\section{Acknowledgements}

This study was supported by the self-determined Foundation of Key Laboratory of Oil Shale and Coexistent Energy Minerals of Jilin Province (No. YYY-ZZ-18-03), and the National Nature Science Foundation of China (Nos. 41790453, 41972313 and 41903067) and was funded by the Key Laboratory for the Evolution of Past Life and Environment in Northeast Asia, Ministry of Education, Jilin University, and the Engineering Research Center 
of Geothermal Resources Development Technology and Equipment, Ministry of Education, Jilin University. Thanks are due to Ms. Chenyang Wu for her contribution to and assistance in this study.

\section{REFERENCES}

1. Owens, J. D., Gill, B. C., Jenkyns, H. C., Bates, S. M., Severmann, S., Kuypers, M. M. M., Woodfine, R. G., Lyons, T. W. Sulfur isotopes track the global extent and dynamics of euxinia during Cretaceous Oceanic Anoxic Event 2. Proc. Natl. Acad. Sci. U.S.A., 2013, 110(46), 18407-18412.

2. Arthur, M. A., Jenkyns, H. C., Brumsack, H.-J., Schlanger, S. O. Stratigraphy, geochemistry, and paleoceanography of organic carbon-rich Cretaceous sequences. In: Cretaceous Resources, Events and Rhythms (Ginsburg, R. N., Beaudoin, B., eds.), NATO ASI Series (Series C: Mathematical and Physical Sciences), 1990, 304, 75-119.

3. Poulsen, C. J., Barron, E. J., Arthur, M. A., Peterson, W. H. Response of the mid-Cretaceous global oceanic circulation to tectonic and $\mathrm{CO}_{2}$ forcings. Paleoceanography, 2001, 16(6), 576-592.

4. Schlanger, S. O., Arthur, M. A., Jenkyns, H. C., Scholle, P. A. The CenomanianTuronian oceanic anoxic event, 1 . Stratigraphy and distribution of organic carbonrich beds and the marine $\delta^{13}$ excursion. In: Marine Petroleum Source Rocks (Brooks, J., Fleet, A. J., eds.), Geological Society, London, Special Publications, 26, 1987, 371-399.

5. Wagreich, M. "OAE3" - regional Atlantic organic carbon burial during the Coniacian-Santonian. Clim. Past, 2012, 8(5), 1447-1455.

6. Deng, C. L., He, H. Y., Pan, Y. X., Zhu, R. X. Chronology of the terrestrial Upper Cretaceous in Songliao Basin, Northeast Asia. Palaeogeogr. Palaeoecol., 2013, 385, 44-54.

7. Wan, X. Q., Li, G., Chen, P. J., Yu, T., Ye, D. Q. Isotope stratigraphy of the Cretaceous Qingshankou Formation in Songliao Basin and its correlation with marine Cenomanian stage. Acta Geol. Sin-Engl., 2005, 79(2), 150-156.

8. Norton, I. O. Speculations on Cretaceous tectonic history of the northwest Pacific and a tectonic origin for the Hawaii hotspot. In: Plates, Plumes, and Planetary Processes (Foulger, G. R., Jurdy, D. M., eds.), The Geological Society of America, Special Paper, 2007, 430, 451-470.

9. Yang, Y. T. An unrecognized major collision of the Okhotomorsk Block with East Asia during the Late Cretaceous, constraints on the plate reorganization of the Northwest Pacific. Earth Sci. Rev., 2013, 126, 96-115.

10. Chen, R. J. (1980) Characteristics of glauconites from some regions and their significance in analyzing the facies environments. Scientia Geologic Sinica, 66, 65-79. https://link.springer.com/article/10.1346/CCMN.2017.064081

11. Xing, S. J., Xiao, Z. S., Zhang, C. S. Mineralogy Characteristics and Formation Conditions of Glauconite in Taikang Bay. Petroleum Geology of Songliao Continental Basin. Petroleum Industry Press, Beijing, 1985 (in Chinese). 
12. Hou, D. J., Li, M. W., Huang, Q. H. Marine transgressional events in the gigantic freshwater lake Songliao: paleontological and geochemical evidence. Org. Geochem., 2000, 31(7-8), 763-768.

13. Song, Z. G., Qin, Y., Geroge, S. C., Wang, L., Guo, J. T., Feng, Z. H. A biomarker study of depositional paleoenvironments and source inputs for the massive formation of Upper Cretaceous lacustrine source rocks in the Songliao Basin, China. Palaeogeogr. Palaeoecol., 2013, 385, 137-151.

14. Xi, D. P., Wan, X. Q., Feng, Z. Q., Li, S., Feng, Z.H., Jia, J. Z., Jing, X., Si, W. M. Discovery of Late Cretaceous foraminifera in the Songliao Basin: evidence from SK1 and implications for identifying seawater incursions. Chinese Sci. Bull., 2011, 56(3), 253-256.

15. Cao, H. S., Kaufman, A. J., Shan, X. L., Cui, H., Zhang, G. J. Sulfur isotope constraints on marine transgression in the lacustrine Upper Cretaceous Songliao Basin, northeastern China. Palaeogeogr. Palaeoecol., 2016, 451, 152-163.

16. Huang, Y. J., Yang, G. S., Gu, J., Wang, P. K., Huang, Q. H., Feng, Z. H., Feng, L. J. Marine incursion events in the Late Cretaceous Songliao Basin: constraints from sulfur geochemistry records. Palaeogeogr. Palaeoecol., 2013, 385, 152-161.

17. Feng, Z. Q., Jia, C. Z., Xie, X. N., Zhang, S., Feng, Z. H., Cross, T. A. Tectonostratigraphic units and stratigraphic sequences of the nonmarine Songliao Basin, northeast China. Basin Res., 2010, 22(1), 79-95.

18. Song, T. G. Inversion styles in Songliao basin (northeast China) and estimation of the degree of inversion. Tectonophysics, 1997, 283(1), 173-188.

19. Wu, H. C., Zhang, S. H., Jiang, G. Q., Huang, Q. H. The floating astronomical time scale for the terrestrial Late Cretaceous Qingshankou Formation from the Songliao Basin of Northeast China and its stratigraphic and paleoclimate implications. Earth Planet. Sci. Lett., 2009, 278(3-4), 308-323.

20. Holmes, J. A., Chivas, A. R. Ostracode shell chemistry-Overview. In: The Ostracoda: Applications in Quaternary Research (Holmes, J. A., Chivas, A .R., eds.), Geophysical Monograph Series 131. American Geophysical Union, Washington DC, 2002, 183-204.

21. Gao, R., He, C., Qiao, X. A new genus and species of Cretaceous dinoflagellates from two transgressive beds in Songliao Basin, NE China. Acta Palaeontol. Sin., 1992, 31(1), 17-29 (in Chinese with English abstract).

22. Collister, J. W., Lichtfouse, E., Hieshima, G., Hayes, J. M. Partial resolution of sources of $n$-alkanes in the saline portion of the Parachute Creek Member, Green River Formation(Piceance Creek Basin, Colorado). Org. Geochem., 1994, 21(6-7), 645-659.

23. Peters, K. E., Moldowan, J. M. The Biomarker Guide: Interpreting Molecular Fossils in Petroleum and Ancient Sediments. Englewood Cliffs, N. J., Prentice Hall, 1993.

24. Lijmbach, G. W. On the origin of petroleum. Proceedings of the 9th World Petroleum Congress, Tokyo, Japan, 11-16 May 1975. Applied Science Publishers, London, 1975, 2, 357-369. 
25. Shanmugam, G. Significance of coniferous rain forests and related organic matter in generating commercial quantities of oil, Gippsland Basin, Australia. AAPG Bulletin, 1985, 69(8), 1241-1254.

26. Makeen, Y. M., Abdullah, W. H., Hakimi, M. H. Biological markers and organic petrology study of organic matter in the Lower Cretaceous Abu Gabra sediments (Muglad Basin, Sudan): Origin, type and palaeoenvironmental conditions. Arab. J. Geosci., 2015, 8(1), 489-506.

27. Makeen, Y. M., Hakimi, M. H., Abdullah, W. H. The origin, type and preservation of organic matter of the Barremiane-Aptian organic-rich shales in the Muglad Basin, Southern Sudan, and their relation to paleoenvironmental and paleoclimate conditions. Mar. Petrol. Geol., 2015, 65, 187-197.

28. Makeen, Y. M., Abdullah, W. H., Hakimi, M. H., Elhassan, O. M. A. Organic geochemical characteristics of the Lower Cretaceous Abu Gabra Formation in the Great Moga oilfield, Muglad Basin, Sudan: implications for depositional environment and oil-generation potential. J. Afr. Earth Sci., 2015, 103, 102-112.

29. Qin, J., Wang, S., Sanei, H., Jiang, C., Chen, Z., Ren, S., Xu, X., Yang, J., Z. Revelation of organic matter sources and sedimentary environment characteristics for shale gas formation by petrographic analysis of middle Jurassic Dameigou formation, northern Qaidam Basin, China. Int. J. Coal Geol., 2018, 195(1), 373-385.

30. Huang, W. Y., Meinschein, W. G. Sterols as ecological indicators. Geochim. Cosmochim. Acta, 1979, 43(5), 739-745.

31. Mackenzie, A. S., Brassell, S. C., Eglinton, G., Maxwell, J. R. Chemical fossils: the geological fate of steroids. Science, 1982, 217(4559), 491-504.

32. Sinninghe Damste, J. S., Kenig, F., Koopmans, M. P., Köster, J., Schouten S., Hayes, J. M., De Leeuw, J. W. Evidence for gammacerane as an indicator of water column stratification. Geochim. Cosmochim. Acta, 1995, 59(9), 1895-1900.

33. Schoell, M., Hwang, R. J., Carlson, R. M. K., Welton, J. E. Carbon isotopic composition of individual biomarkers in gilsonites (Utah). Org. Geochem., 1994, 21(6-7), 673-683.

34. Mello, M. R., Telnaes, N., Gaglianone, P. C., Chicarelli, M. I., Brassell, S. C., Maxwell, J. R. Organic geochemical characterization of depositional palaeoenvironments of source rocks and oils in Brazilian marginal basins. Org. Geochem., 1988, 13(1-3), 31-45.

35. Sofer, Z. V. Isotopic composition of individual n-alkane in oils. Organic Geochemistry, The 15th Meeting 1992. 23: 210-212.

36. Zhao, M. J., Huang, D. F. Carbon isotopic distributive characteristics of crude oil monomers produced in different sedimentary environments. Petroleum Geology and Experiment, 1995, 17(2), 171-179 (in Chinese).

37. Quan, C., Sun, C., Sun, Y., Sun, G. High resolution estimates of paleo-CO levels through the Campanian (Late Cretaceous) based on Ginkgo cuticles. Cretaceous Res., 2009, 30(2), 424-428.

38. Cerling, T. E. Stable carbon isotopes in palaeosol carbonates. In: Palaeoweathering, Palaeosurfaces, and Related Continental Deposits (Thiry, M., Simon-Coinçon, R., eds.). Spec. Public. Int. Assoc. Sediment., 1999, 27, 43-60. 
39. Hong, S. K., Lee, Y. I. Contributions of soot to $\delta^{13} \mathrm{C}$ of organic matter in Cretaceous lacustrine deposits, Gyeongsang Basin, Korea: Implication for paleoenvironmental reconstructions Santonian-Campanian Boundary Event. Palaeogeogr. Palaeoecol., 2013, 371, 54-61.

40. Tajika, E. Carbon cycle and climate change during the Cretaceous inferred from a biogeochemical carbon cycle model. Isl. Arc, 1999, 8(2), 293-303.

41. Yan, J. J. Mid-Cretaceous Biostratigraphy and Palaeoclimate Change from the Qingshankou and Nenjiang Formations in Nong'an area, Jilin Province. Master's Thesis, China University of Geosciences, 2009.

42. Bechtel, A., Jia, J., Strobl, S. A. I., Sachsenhofer, R. F., Liu, Z., Gratzer, R., Püttmann, W. Palaeoenvironmental conditions during deposition of the Upper Cretaceous oil shale sequences in the Songliao Basin (NE China): Implications from geochemical analysis. Org. Geochem., 2012, 46, 76-95.

43. Brunner, B., Bernasconi, S. M. A revised isotope fractionation model for dissimilatory sulfate reduction in sulfate reducing bacteria. Geochim. Cosmochim. Acta, 2005, 69(20), 4759-4771.

44. Goldhaber, M. B., Kaplan, I. R. The sulfur cycle. In: The Sea (Goldberg, E. D., ed.), Chichester, UK, 1974, 5, 569-655.

45. Berner, R. A. Burial of organic carbon and pyrite sulfur in the modern ocean; its geochemical and environmental significance. Am. J. Sci., 1982, 282(4), 451-473.

46. Berner, R. A., Raiswell, R. C/S method for distinguishing freshwater from marine sedimentary rocks. Geology, 1984, 12(6), 365-368.

47. Berner, R. A., Raiswell, R. Burial of organic carbon and pyrite sulfur in sediments over phanerozoic time: a new theory. Geochim. Cosmochim. Acta, 1983, 47(5), $855-862$.

48. Leventhal, J. S. An interpretation of carbon and sulfur relationships in Black Sea sediments as indicators of environments of deposition. Geochim. Cosmochim. Acta, 1983, 47(1), 133-138.

49. McKay, J. L., Longstaffe, F. J. Sulphur isotope geochemistry of pyrite from the Upper Cretaceous Marshybank Formation, Western Interior Basin. Sediment. Geology, 2003, 157(3), 175-195.

50. Sachse, V. F., Littke, R., Jabour, H., Schühmann, T., Kluth, O. Late Cretaceous (Late Turonian, Coniacian and Santonian) petroleum source rocks as part of an OAE, Tarfaya Basin, Morocco. Mar. Petrol. Geol., 2012, 29(1), 35-49.

51. Dean, W. E., Gorham, E. Magnitude and significance of carbon burial in lakes, reservoirs, and peatlands. Geology, 1998, 26(6), 535-538.

52. Jia, J., Bechtel, A., Liu, Z., Strobl, S. A. I., Sun, P., Sachsenhofer, R. F. Oil shale formation in the Upper Cretaceous Nenjiang Formation of the Songliao Basin (NE China): Implications from organic and inorganic geochemical analyses. Int. J. Coal Geol., 2013, 113, 11-26.

53. Song, Z. G., Qin, Y., Geroge, S. C., Wang, L., Guo, J. T., Feng, Z. H. A biomarker study of depositional paleoenvironments and source inputs for the massive formation of Upper Cretaceous lacustrine source rocks in the Songliao Basin, China. Palaeogeogr. Palaeoecol., 2013, 385, 137-151. 
54. Habicht, K. S., Gade, M., Thamdrup, B., Berg, P., Canfield, D. E. Calibration of sulfate levels in the Archean ocean. Science, 2002, 298(5602), 2372-2374.

55. Canfield, D. E., Thamdrup, B. The production of ${ }^{34}$ S-depleted sulfide during bacterial disproportionation of elemental sulfur. Science, 1994, 266(5193), 19731975.

56. Brenot, A., Carignan, J., France-Lanord, C., Benoît, M. Geological and land use control on $\delta^{34} \mathrm{~S}$ and $\delta^{18} \mathrm{O}$ of river dissolved sulfate: the Moselle River basin, France. Chem. Geol., 2007, 244(1-2), 25-41.

57. Hirst, D. M. Geochemistry of sediments from eleven Black Sea cores. In: The Black Sea - Geology, Chemistry, and Biology (Degens, E. T., Ross, D. A., eds.), AAPG Memoir, 1974, 20, 430-455.

58. Schoonen, M. A. A. Mechanisms of sedimentary pyrite formation. In: Sulfur Biochemistry - Past and Present (Amend, J. P., Edwards, K. J., Lyons, T. W., eds.), GSA Special Papers, 2004, 379, 117-134.

59. Hou, D. J., Feng, Z. H., Huang, Q. H. Geological and geochemical evidences of anoxic event in the Songliao Basin, China. Geoscience, 2003, 17(3), 311-317 (in Chinese).

60. Gomes, M. L., Hurtgen, M. T. Sulfur isotope fractionation in modern euxinic systems: implications for paleoenvironmental reconstructions of paired sulfatesulfide isotope records. Geochim. Cosmochim. Acta, 2015, 157, 39-55.

61. Wu, N., Farquhar, J., Fike, D. A. Ediacaran sulfur cycle: insights from sulfur isotope measurements $\left(\delta^{33} \mathrm{~S}\right.$ and $\left.\delta^{34} \mathrm{~S}\right)$ on paired sulfate-pyrite in the Huqf supergroup of Oman. Geochim. Cosmochim. Acta, 2015, 164, 352-364.

62. Wang, P. J., Wang, D. P., Du, X. D. The origin of the black shales and the bottom current model for seawater encroachment in the Cretaceous Qingshankou Formation, Songliao Basin, Northeast China. Sedimentary Facies and Palaeogeography, 1996, 16(1), 34-43 (in Chinese).

63. Gill, B. C., Lyons, T. W., Jenkyns, H. C. A global perturbation to the sulfur cycle during the Toarcian Oceanic Anoxic Event. Earth Planet. Sci. Lett., 2011,312(3-4), 484-496.

64. Logan, G.. A., Hayes, J. M., Hieshima, G. B., Summons, R. E. Terminal Proterozoic reorganization of biogeochemical cycles. Nature, 1995, 376(6535), $53-56$.

65. Shen, B., Xiao, S., Kaufman, A. J., Bao, H., Zhou, C., Wang, H. Stratification and mixing of a post-glacial Neoproterozoic ocean: Evidence from carbon and sulfur isotopes in a cap dolostone from northwest China. Earth Planet. Sci. Lett., 2008, 265(1-2), 209-228. 